\title{
Prevention in primary care is better than cure: The Hong Kong Reference Framework for Preventive Care for Older Adults-translating evidence into practice
}

\author{
Cecilia KL Sin, SN Fu, Caroline SH Tsang *, Wendy WS Tsui, Felix HW Chan
}

\section{A B S T R A C T}

An ageing population is posing a great challenge to Hong Kong. Maintaining health and functional independence among older adults is of utmost importance, and requires the collaborative efforts of multiple health care disciplines from both the private and public sectors. The Reference Framework for Preventive Care for Older Adults, developed by the Task Force on Conceptual Model and Preventive Protocols under the auspices of the Working Group on Primary Care, aims to enhance primary care for this population group. The reference framework emphasises a comprehensive, integrated, and collaborative approach that involves providers of primary care from multiple disciplines. In addition to internet-based information, helpful tools in the form of summary charts and Cue Cards are also produced to facilitate incorporation of recommendations by primary care providers into their daily practice. It is anticipated that wide adoption of the reference framework will contribute to improving older adults' health in our community.

\section{Hong Kong Med J 2015;21:353-9} DOI: $10.12809 / \mathrm{hkmj} 144326$

${ }^{1}$ CKL Sin, MB, BS, FHKAM (Family Medicine)

${ }^{1}$ SN Fu, MB, BS, FHKAM (Family Medicine)

CSH Tsang *, MB, ChB, FHKAM (Community Medicine)

${ }^{1}$ WWS Tsui, MB, ChB, FHKAM (Family Medicine)

${ }^{2}$ FHW Chan, MBBCh, FHKAM (Medicine)

1 Primary Care Office, Department of Health, Hong Kong

2 Clinical Advisory Group on Reference Framework for Preventive Care for Older Adults in Primary Care Settings, Hong Kong

* Corresponding author: caroline_tsang@dh.gov.hk

\section{Introduction}

Advances in medicine and increased life expectancy mean that Hong Kong is expecting an ageing population, and a significant increase in the number and proportion of older adults. According to the Census and Statistics Department of Hong Kong SAR, it is estimated that by 2041, the number of Hong Kong residents aged 65 years and above will increase from 0.9 million in 2011 (13\% of the population) to around 2.6 million (30\% of the projected population). ${ }^{1}$

This ageing population poses not only a threat but also a challenge to the current health care system. It is anticipated that the prevalence of common chronic diseases will be further increased with a consequent escalating demand on various health services for older adults. Strategies to promote health, prevent chronic diseases, and preserve functional ability of older adults are therefore vital.

In order to provide a general reference for provision of continuous, comprehensive, and evidence-based care for older adults in the primary care setting, the Reference Framework for Preventive Care for Older Adults in Primary Care Settings ${ }^{2}$ was developed by the Task Force on Conceptual Model and Preventive Protocols under the auspices of the
Working Group on Primary Care. It was developed according to the latest research evidence, with contributions from the Clinical Advisory Group that comprises experts from academia, professional organisations, private and public primary care sectors, and patient groups.

The reference framework consists of a core document supplemented by a series of modules that address various aspects of disease management and preventive care for older adults. ${ }^{2}$ To date, the core document, and the modules on health assessment and falls have been developed.

This article summarises the main contents and highlights a practical use of this reference framework to enhance the delivery of preventive care for older adults in primary care setting in Hong Kong. Details of the evidence that supports the recommendations are available in the core document of the reference framework. $^{2}$

\section{Role of primary care in the preventive care of older adults}

As the first point of contact, primary care providers are in a prime position to promote health, prevent and monitor disease, and reduce functional disabilities. ${ }^{3}$ Primary care physicians provide health 
預防勝於治療 : 《香港長者護理參考概覽一一長 者在基層醫療的預防護理》一一由實證到實踐

冼嘉玲、傅秀雅、曾守衡、徐詠詩、陳漢威

人口老化是香港的一大挑戰, 因此維持長者健康及其自理能力是非常 重要的一環。要達到這目的, 有賴公私營界別的跨專業團隊緊密合 作。《香港長者護理參考概覽一一長者在基層醫療的預防護理》是由 基層醫療工作小組轄下的基層醫療概念模式及預防工作常規專責小組 編製, 目的是為加強長者的基層醫療護理。參考概覽強調全面、綜合 和着重合作, 並由跨專業團隊提供基層醫療護理。除了於互聯網發放 有關資料, 我們亦製作摘要圖表及提示卡等輔助工具, 方便醫護人員 在日常工作中參閲。我們相信廣泛採納此參考概覽將有助提昇社區長 者的健康。

\section{Practice of evidence-based recommendations for older adults with different functional capacity}

Older adults vary in their needs and functional capacity. In a healthy active older adult, the emphasis will often be on health promotion and diseaseprevention activities. At the other extreme, a frail older adult with additional special needs will require a comprehensive assessment and formulation of an individualised care plan. The needs and condition of an older adult may also change over time. It is not uncommon to see a healthy active older adult suddenly becomes disabled following an untoward event.

In order to formulate a personalised care plan and effectively implement the evidence-based recommendations, three categories of functional capacity of older adults have been proposedindependent with no known chronic diseases, independent with chronic diseases, and older adults with disabilities.

For all older adults and as far as applicable, promotion of a healthy lifestyle and early identification and appropriate management of risk factors-such as unhealthy diet, physical inactivity, and tobacco use-should form the cornerstone in prevention or management of chronic diseases. A healthy lifestyle is known to be positively associated with better physical and mental health as well as longevity, reduced risk of chronic diseases, and more quality-adjusted life years. ${ }^{33,34}$ Thus promoting a healthy lifestyle should be one of the main focuses in healthy ageing.

For older adults of all functional stages, a healthy lifestyle and modification of behavioural risk factors should be promoted as much as is practical. Table 2 provides a summary of the recommendations.

\section{Independent with no known chronic disease}

Staying active and healthy is essential to the quality of life. The functional decline that occurs with ageing may be due, at least in part, to lifestyle, behaviour, diet, and the environment, which are all modifiable factors. ${ }^{35}$

The primary objective for this category of older adults is to maintain optimal functional capacity and prevent or delay the development of chronic disease, thus helping to extend a healthy active life. In addition to health education and promotion, a systemic health assessment and early identification of chronic diseases are important.

The recommended items for assessment in this category of older adults are listed in Table 3. Details of preventive care can be found in the respective chapter of the core document ${ }^{2}$ and/or module quoted in brackets. 
TABLE I. Summary of recommendations on preventive care for older adults in primary care settings

\begin{tabular}{|c|c|}
\hline Health domain & Recommendation \\
\hline Vaccination $^{9,10}$ & $\begin{array}{l}\text { - Annual seasonal influenza vaccination is recommended for older adults aged } \geq 65 \text { years and those high-risk groups } \\
\text { - Single dose of } 23 \text {-valent pneumococcal polysaccharide vaccination ( } 23 \mathrm{vPPV} \text { ) is recommended for those who have } \\
\text { never received any } 23 \mathrm{vPPV} \text { before, or have received one dose of } 23 \mathrm{vPPV} \text { before } 65 \text { years but }>5 \text { years earlier }\end{array}$ \\
\hline $\begin{array}{l}\text { Practice of healthy } \\
\text { lifestyle }\end{array}$ & $\begin{array}{l}\text { - Smoking }{ }^{11,12} \\
\text { - Ask about tobacco use at every opportunity and advise all current smokers to quit smoking } \\
\text { - Asinking } \\
\text { - Assess the quantity and frequency of alcohol intake in all older adults } \\
\text { - Advise on drinking to minimise alcohol-related harm } \\
\text { - Asseal activity }{ }^{14} \\
\text { - Obesity }{ }^{15} \\
\text { - Screen all older adults on current level of activities and promote regular physical activity whenever possible } \\
\quad \text { weight }\end{array}$ \\
\hline Dental health ${ }^{16}$ & $\begin{array}{l}\text { - It is recommended to promote oral hygiene as part of general health education and assess for oral health } \\
\text { problems periodically }\end{array}$ \\
\hline Chronic diseases & $\begin{array}{l}\text { - Hypertension }{ }^{17,18} \\
\text { - Annual screening of hypertension is recommended for older adults } \\
\text { Diabetes mellitus }{ }^{19,20} \\
\text { - Periodic screening of diabetes mellitus is recommended for adults starting from } 45 \text { years old } \\
\text { - Screen for diabetes mellitus every } 3 \text { years if previous results are normal and more frequent testing, eg every } 12 \\
\text { - } \text { months is recommended when risk factors are present } \\
\text { - Perlipidaemia }{ }^{21.22} \\
\text { - Screen for hyperlipidaemia every } 3 \text { years if previous results are within optimal range and more frequent testing, } \\
\text { eg every } 12 \text { months is recommended when risk factors of cardiovascular diseases are present }\end{array}$ \\
\hline Cancers & $\begin{array}{l}\text { - Cervical cancer } 23 \\
\text { - Women aged } 25-64 \text { years who have ever had sex are recommended to have cervical cytology test every } 3 \\
\text { years after two consecutive normal annual cytology tests } \\
\text { - Screening may be discontinued in women aged } \geq 65 \text { years if three previous consecutive tests are normal } \\
\text { - Women }>65 \text { years who have never had cervical cytology, or who request a cervical cytology test, should also } \\
\text { - be screened } \\
\text { - Asymptomatic average-risk individuals aged } 50-75 \text { years should consider screening for colorectal cancer by } \\
\text { one of the screening methods including annual or biennial faecal occult blood test, flexible sigmoidoscopy } \\
\text { every } 5 \text { years, and colonoscopy every } 10 \text { years }\end{array}$ \\
\hline Functional disability & $\begin{array}{l}\text { - Hearing impairment }{ }^{25} \\
\text { - Opportunistic screening of hearing impairment is recommended for community-dwelling older adults } \\
\text { - Iisual impairment }{ }^{21,26} \\
\text { - Opportunistic screening of visual impairment is recommended for community-dwelling older adults } \\
\text { - Opportunistic screening of urinary incontinence is recommended for older adults } \\
\text { - Falls }{ }^{28} \\
\text { - Primary care providers are recommended to assess the risk of falls in older adults opportunistically }\end{array}$ \\
\hline Mental disorders & $\begin{array}{l}\text { - Depression } 21,29 \\
\text { - Opportunistic screening of depression is recommended for older adults } \\
\text { - Pementia }{ }^{30} \\
\text { - Primary care providers should assess cognitive function whenever cognitive impairment or deterioration is } \\
\text { suspected, based on direct observation, patient report, or concerns raised by family members or carers }\end{array}$ \\
\hline $\begin{array}{l}\text { Polypharmacy and } \\
\text { adverse drug reactions }{ }^{31}\end{array}$ & $\begin{array}{l}\text { - When prescribing new drugs to the older patients, health care professionals should review all the medications } \\
\text { (including over-the-counter drugs and herbal remedies) so as to avoid possible drug duplications, interactions, or } \\
\text { adverse drug reactions }\end{array}$ \\
\hline $\begin{array}{l}\text { Assessment of social } \\
\text { network and support }{ }^{32}\end{array}$ & $\begin{array}{l}\text { - Opportunistic screening on the social support networks of older adults, including the social needs and the extent } \\
\text { and availability of social support available is recommended } \\
\text { - It is recommended to provide personalised support to carers enabling them to remain mentally and physically well }\end{array}$ \\
\hline
\end{tabular}

\section{Independent with chronic diseases}

Older adults with chronic diseases vary in clinical heterogeneity, number of chronic conditions, severity of illness, and functional limitations. Chronic diseases exert a synergistic effect such that the combined disabling effect of different diseases is greater than the combined effect of each. ${ }^{36}$ As the number of chronic diseases in an individual increases, the risk of mortality, poor functional status, unnecessary hospitalisations, and adverse drug events also increases. ${ }^{37-39}$ Multiple chronic diseases can be accompanied by loss of function, reduced independence, and increased risk of depressive illness. These subsequently contribute to frailty and disability. ${ }^{37,40}$

The objectives of preventive services in these 
older adults are to appropriately manage their chronic diseases with reference to both secondary and tertiary prevention, as well as to maintain functional independence. The recommendations on preventive care for independent older adults with chronic diseases are summarised in Table 4. Details about preventive care can be found in the relevant chapter of the core document and/or module quoted in brackets. ${ }^{2}$

\section{Older adults with disabilities}

Older adults who suffer multiple debilitating diseases (such as stroke, dementia, or arthritis) are likely to face disabling barriers that inhibit or prevent their integration into the community. Chronic pain is also common in this group of older adults and invariably jeopardises physical, psychological, and social wellbeing.

The approach to this group is early intervention to prevent further loss of function, so as to maintain optimal functional capacity and improve quality of life, and also facilitate integration into society for those who have relatively mild disability. A comprehensive assessment should be offered to this group of older adults with complex needs, and should encompass physical, psychological, and social

TABLE 2. Recommendations on lifestyle advice

\begin{tabular}{ll}
\hline Preventive care & Recommendation \\
\hline Vaccination & $\begin{array}{l}\text { Arrange seasonal influenza vaccination annually } \\
\text { Arrange pneumococcal vaccination as appropriate }\end{array}$ \\
\hline Smoking & $\begin{array}{l}\text { Smoking cessation advice } \\
\text { Drinking }\end{array}$ \\
$\begin{array}{l}\text { Minimisation of alcohol intake } \\
\text { Physical activity }\end{array}$ & Advise regular physical activities \\
\hline Oral health & Advise healthy eating habit and balanced diet \\
\hline
\end{tabular}

TABLE 3. Recommendations on preventive care for independent older adults with no known chronic diseases

\begin{tabular}{ll}
\hline Preventive care & Recommendation (respective chapter in the core document ${ }^{2}$ ) \\
\hline Health education and promotion & Vaccination, healthy lifestyle, nutrition, oral health (Chapter 5.1-5.4.2) \\
\hline Screening for hypertension & Measure blood pressure (Chapter 5.4.1a) \\
Screening for diabetes mellitus & Check blood for fasting blood sugar (Chapter 5.4.1b) \\
Screening for hyperlipidaemia & Check blood for lipid profile (Chapter 5.4.1c) \\
$\begin{array}{l}\text { Screening for overweight and } \\
\text { underweight }\end{array}$ & Check body mass index \pm waist circumference (Chapter 5.2.4) \\
Screening for cervical cancer & Check cervical cytology test (Chapter 5.4.2a) \\
Screening for colorectal cancer & Check faecal occult blood test (Chapter 5.4.2b) \\
Screening for functional impairment & Hearing, vision, incontinence, falls, dental, depression, dementia*, social isolation (Chapter 5.4.3-5.5) \\
\hline
\end{tabular}

* Primary care providers should assess cognitive function whenever cognitive impairment or deterioration is suspected

TABLE 4. Recommendations on preventive care for independent older adults with chronic diseases

\begin{tabular}{|c|c|}
\hline Preventive care & Recommendation (respective chapter in the core document ${ }^{2}$ ) \\
\hline $\begin{array}{l}\text { Risk assessment of hypertension and diabetes } \\
\text { mellitus (if any) }\end{array}$ & Risk assessment for secondary and tertiary prevention (Chapter 5.4.1) \\
\hline Review use of medications & Screen for problems related to medication use and polypharmacy (Chapter 5.4.5) \\
\hline Screen for overweight and underweight & $\begin{array}{l}\text { Check body mass index } \pm \text { waist circumference (Chapter } 5.2 .4 \text { ) } \\
\text { Monitor body weight and assess risk of malnutrition (Chapter } 5.2 .6 \text { and Module on Health } \\
\text { Assessment) }\end{array}$ \\
\hline Opportunistic screening of functional impairment & $\begin{array}{l}\text { Hearing, vision, incontinence, falls, dental health, depression, dementia*, social isolation } \\
\text { (Chapter } 5.4 .3-5.5)\end{array}$ \\
\hline Screening for abilities on self-care and daily living & $\begin{array}{l}\text { Screen for daily living problems by basic ADL and instrumental ADL (Module on Health } \\
\text { Assessment) }\end{array}$ \\
\hline Assess social network and support & Assess the need of social and carer support (Chapter 5.5) \\
\hline
\end{tabular}

Abbreviation: $\mathrm{ADL}=$ activity of daily living

* Primary care providers should assess cognitive function whenever cognitive impairment or deterioration is suspected 


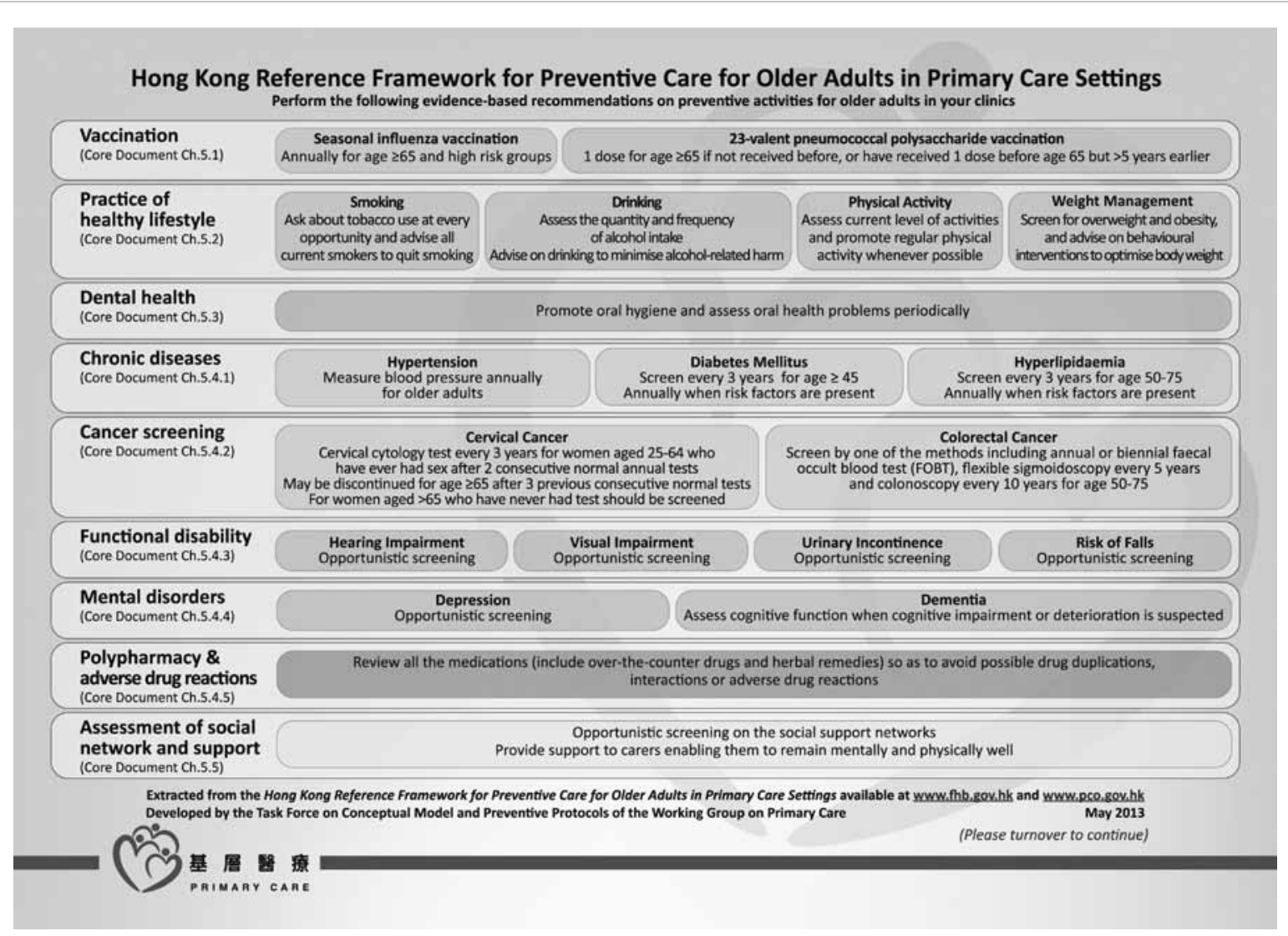

Practice

FIG. Two-page summary of the Hong Kong Reference Framework for Preventive Care for Older Adults in Primary Care Settings 
TABLE 5. Recommendations on preventive care for older adults with disabilities

\begin{tabular}{ll}
\hline Preventive care & Recommendation (respective chapter in the core document ${ }^{2}$ ) \\
\hline Assess the abilities on self-care and daily living & $\begin{array}{l}\text { Assess functioning of daily living in the community by basic ADL and instrumental ADL } \\
\text { (Module on Health Assessment) }\end{array}$ \\
\hline Opportunistic screening of functional impairment & $\begin{array}{l}\text { Hearing, vision, incontinence, falls, dental health, depression, dementia*, social isolation } \\
\text { (Chapter 5.4.3-5.5) }\end{array}$ \\
Assess risk of malnutrition & $\begin{array}{l}\text { Check BMI and monitor body weight (Chapter 5.2.6 and Module on Health Assessment) } \\
\text { Review use of medications }\end{array}$ \\
Assess social network and support & Screen for problems related to medication use and polypharmacy (Chapter 5.4.5) \\
\hline
\end{tabular}

Abbreviations: $\mathrm{ADL}=$ activity of daily living; $\mathrm{BMI}=$ body mass index

* Primary care providers should assess cognitive function whenever cognitive impairment or deterioration is suspected

aspects of care (eg ability in self-care, hearing and visual impairment, incontinence, falls, depression, cognitive impairment, malnutrition, polypharmacy, social support, and carer stress).

The recommendations on preventive care for older adults with disabilities are listed in Table 5. Details about preventive care can again be found in the relevant chapter of the core document and/or module quoted in brackets. ${ }^{2}$

\section{The two-page summary}

A 2-page summary (Fig) has been developed to provide a quick reference for primary care providers on preventive care for older adults. It provides a summary of the evidence-based recommendations for preventive activities and the practice of recommendations for older adults with different functional capacities. The relevant chapter of the preventive care is stated in the summary for further information and supporting evidence. It can also be downloaded from the Primary Care Office website (http://www.pco.gov.hk/english/resource/files/ Summary_page_older_adult.pdf).

\section{Patient education materials}

In a busy clinic, patient education material is an effective means to deliver preventive care information to patients and their carers. The resources related to the health care of older adults are available in Annex 3 of the core document. ${ }^{2}$ These resources provide information for the local community and help primary care providers coordinate care with other professionals and specialists. Families can also be put in touch with community-based services. With appropriate care, older adults can achieve optimum health and improve their quality of life.

\section{Conclusion}

Effective preventive care of older adults can be achieved through health education and promotion, prevention and monitoring of diseases, and reduction of functional disabilities. Primary care providers play an important role in providing patient-centred, comprehensive, continuing, and coordinated preventive care to older adults in the community. In addition, continued efforts of different health care providers, professional organisations, social service agencies, and all stakeholders are needed to provide a supportive environment for active and healthy ageing. It is hoped that through the development and promotion of this reference framework, more emphasis can be placed on preventive care in older adults. This will improve their health and promote healthy ageing.

\section{References}

1. Hong Kong Population Projections 2012-2041. Census and Statistics Department, HKSAR. 2012 July. Available from: http://www.statistics.gov.hk/pub/ B1120015052012XXXXB0100.pdf. Accessed Jun 2015.

2. Hong Kong Reference Framework for Preventive Care for Older Adults in Primary Care Settings 2012. Available from: http://www.pco.gov.hk/english/resource/files/ref framework_adults.pdf. Accessed 11 Nov 2014.

3. Brotons C, Bulc M, Sammut MR, et al. Attitudes toward preventive services and lifestyle: the views of primary care patients in Europe. The EUROPREVIEW patient study. Fam Pract 2012;29 Suppl 1:i168-76.

4. Wallace LS, Rogers ES, Roskos SE, Holiday DB, Weiss BD. Brief report: screening items to identify patients with limited health literacy skills. J Gen Intern Med 2006;21:8747.

5. Lo YY, Lam CL, Mercer SW, et al. Patient morbidity and management patterns of community-based primary health care services in Hong Kong. Hong Kong Med J 2011;17(3 Suppl 3):33-7.

6. Canadian Task Force on the Periodic Health Examination. The Periodic Health Examination 1984. A Report of the Periodic Health Examination Task Force. Ottawa, Ontario: Health Services Directorate, Health Services and Promotion Branch, Department of National Health and Welfare; 1984: 15.

7. US Preventive Services Task Force. Guide to clinical preventive services. 2nd ed. Baltimore, MD: Williams \& Wilkins; 1996.

8. Lam CL, Leung GM, Mercer SW, et al. Utilisation patterns of primary health care services in Hong Kong: does having a family doctor make any difference? Hong Kong Med J 2011;17(3 Suppl 3):28-32.

9. Nichol KL, Nordin JD, Nelson DB, Mullooly JP, Hak E. 
Effectiveness of influenza vaccine in the communitydwelling elderly. N Engl J Med 2007;357:1373-81.

10. Moberley SA, Holden J, Tatham DP, Andrews RM. Vaccines for preventing pneumococcal infection in adults. Cochrane Database Syst Rev 2008;(1):CD000422.

11. Ranney L, Melvin C, Lux L, McClain E, Lohr KN. Systematic review: smoking cessation intervention strategies for adults and adults in special populations. Ann Intern Med 2006; 145:845-56.

12. Lam TH, Li ZB, Ho SY, et al. Smoking, quitting and mortality in an elderly cohort of 56,000 Hong Kong Chinese. Tob Control 2007;16:182-9.

13. Whitlock EP, Polen MR, Green CA, Orleans T, Klein J; U.S. Preventive Services Task Force. Behavioral counseling interventions in primary care to reduce risky/harmful alcohol use by adults: a summary of the evidence for the U.S. Preventive Services Task Force. Ann Intern Med 2004;140:557-68.

14. Elward K, Larson EB. Benefits of exercise for older adults. A review of existing evidence and current recommendations for the general population. Clin Geriatr Med 1992;8:35-50.

15. Clinical guidelines on the identification, evaluation, and treatment of overweight and obesity in adults: the Evidence Report. NIH Publication No. 98-4083. National Institutes of Health-National Heart, Lung and Blood InstituteObesity Education Initiative; 1998.

16. Kressin NR, Boehmer U, Nunn ME, Spiro A 3rd. Increased preventive practices lead to greater tooth retention. J Dent Res 2003;82:223-7.

17. Hong Kong Reference Framework for Hypertension Care for Adults in Primary Care Settings. Available from: http:// www.pco.gov.hk/english/resource/files/RF_HT_full.pdf. Accessed Jun 2015.

18. Blood Pressure Lowering Treatment Trialists' Collaboration: Turnbull F, Neal B, Ninomiya T, et al. Effects of different regimens to lower blood pressure on major cardiovascular events in older and younger adults: metaanalysis of randomised trials. BMJ 2008;336:1121-3.

19. Hong Kong Reference Framework for Diabetes Care for Adults in Primary Care Settings. Available from: http:// www.pco.gov.hk/english/resource/files/RF_DM_full.pdf. Accessed Jun 2015.

20. U.S. Preventive Services Task Force. Screening for type 2 diabetes mellitus in adults: U.S. Preventive Services Task Force recommendation statement. Ann Intern Med 2008;148:846-54.

21. The Royal Australian College of General Practitioners. Guidelines for preventive activities in general practice 8th edition. Available from: http://www.racgp.org.au/yourpractice/guidelines/redbook/. Accessed 17 Apr 2014.

22. U.S. Preventive Services Task Force. Screening for lipid disorders in adults: U.S. Preventive Services Task Force recommendation statement. June 2008. Available from: http://www.uspreventiveservicestaskforce.org/uspstf08/ lipid/lipidrs.htm. Accessed 17 Apr 2014.

23. Sasieni PD, Cuzick J, Lynch-Farmery E. Estimating the efficacy of screening by auditing smear histories of women with and without cervical cancer. The National Co-ordinating Network for Cervical Screening Working Group. Br J Cancer 1996;73:1001-5.

24. The Cancer Expert Working Group (CEWG) on Cancer Prevention and Screening. Recommendations on colorectal cancer screening. Available from: http://www.chp.gov.hk/ files/pdf/recommendations_on_crc_screening_2010.pdf. Accessed 17 Apr 2014.

25. Chou R, Dana T, Bougatsos C, Fleming C, Beil T. Screening adults aged 50 years or older for hearing loss: a review of the evidence for the U.S. Preventive Services Task Force. Ann Intern Med 2011;154:347-55.

26. Chou R, Dana T, Bougatsos C. Screening older adults for impaired visual acuity: a review of the evidence for the U.S. Preventive Services Task Force. Ann Intern Med 2009;151:44-58, W11-20.

27. O'Neil B, Gilmour D, Approach to urinary incontinence in women. Diagnosis and management by family physicians. Can Fam Physician 2003;49:611-8.

28. Gillespie LD, Robertson MC, Gillespie WJ, et al. Interventions for preventing falls in older people living in the community. Cochrane Database Syst Rev 2009:(2):CD007146.

29. O'Connor EA, Whitlock EP, Beil TL, Gaynes BN. Screening for depression in adult patients in primary care settings: a systematic evidence review. Ann Intern Med 2009;151:793803.

30. Boustani M, Peterson B, Hanson L, Harris R, Lohr KN; U.S. Preventive Services Task Force. Screening for dementia in primary care: a summary of the evidence for the U.S. Preventive Services Task Force. Ann Intern Med 2003;138:927-37.

31. Steinman MA, Landefeld CS, Rosenthal GE, Berthenthal D, Sen S, Kaboli PJ. Polypharmacy and prescribing quality in older people. J Am Geriatr Soc 2006;54:1516-23.

32. Lou VW. Caregiving burden: congruence of health assessment between caregivers and care receivers. Asian J Gerontol Geriatr 2010;5:21-4.

33. Myint PK, Luben RN, Wareham NJ, Bingham SA, Khaw KT. Combined effect of health behaviours and risk of first ever stroke in 20,040 men and women over 11 years' follow-up in Norfolk cohort of European Prospective Investigation of Cancer (EPIC Norfolk): prospective population study. BMJ 2009;338:b349.

34. Myint PK, Smith RD, Luben RN, et al. Lifestyle behaviours and quality-adjusted life years in middle and older age. Age Ageing 2011;40:589-95.

35. Victor $\mathrm{CH}$, Howse $\mathrm{K}$. Effective health promotion with vulnerable groups: older people. London: Health Education Authority; 1999.

36. Scott KM, Von Korff M, Alonso J, et al. Mental-physical co-morbidity and its relationship with disability: results from the World Mental Health Surveys. Psychol Med 2009;39:33-43.

37. Lee TA, Shields AE, Vogeli C, et al. Mortality rate in veterans with multiple chronic conditions. J Gen Intern Med 2007;22 Suppl 3:403-7.

38. Vogeli C, Shields AE, Lee TA, et al. Multiple chronic conditions: prevalence, health consequences, and implications for quality, care management, and costs. J Gen Intern Med 2007;22 Suppl 3:391-5.

39. Wolff JL, Starfield B, Anderson G. Prevalence, expenditures, and complications of multiple chronic conditions in the elderly. Arch Intern Med 2002;162:2269-76.

40. Von Korff M, Ormel J, Katon W, Lin EH. Disability and depression among high utilizers of health care. A longitudinal analysis. Arch Gen Psychiatry 1992;49:91-100. 